\title{
Ecological Awareness Based on Religious Activities
}

\author{
Muhammad Adhitya Hidayat Putra ${ }^{*}$ Mahfuzah $^{1}$ Bambang Subiyakto ${ }^{1}$

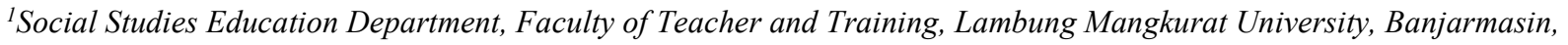 \\ Indonesia \\ ${ }^{*}$ Corresponding author.Email: adhitya.hidayat@ulm.ac.id
}

\begin{abstract}
Religion and environment are considered separate and unrelated things. This understanding has developed so far, has made religion less likely to make a significant contribution to the awareness of the ummah in protecting the environment. Whereas in the Islamic concept, the environment has been introduced by the Koran in various kinds, such as activities carried out by everyone on a daily basis cannot be separated from religious activities. The purpose of this study was to describe the religious activities of the community in Kelayan B RT.27 RW.02. The results of research on the religious activities of the community of Kelayan B RT. 27 RW. 02 is a religious activity that is carried out every day, namely congregational prayers at Langgar Tarbiatul Islamiyah and TPA MIN Kelayan held from Monday to Saturday after midday prayer to Asr, namely learning to read Iqro and the Al-Qur'an. From the results of this study, it is known that most of the community activities do not correlate with awareness of protecting the local environment.
\end{abstract}

Keywords: Religious activities, society, environment.

\section{INTRODUCTION}

One of the biggest elements in the establishment of a country, namely society. Community is a group of people who live and interact together for a long time in a certain area. The important thing of all social life is social interaction because it is impossible for a life to occur without interaction. The social process is a way of communicating that can be seen between individuals and groups that interact and establish a system and pattern of relationships. In social life, people cannot be separated from the existence of social interactions both with the physical environment and the social environment [1].

In the Islamic concept, the environment is introduced by the Koran in various ways. Among them are al-bi'ah (occupying an area, living space and environment), namely the environment as a living space, especially for the human species. The use of the connotation of the environment as a living space seems ecological, which is commonly understood that the environment is everything outside an organism

Religious activity is an activity to carry out religious teachings which is carried out with all faith and sincerity from within that will never be separated from human life. As happened in Kelayan B, which is located in Kelayan B Timur Subdistrict, South Banjarmasin District, Banjarmasin City. From a religious point of view, the people of Kelayan B are already developing. Residents of Kelayan B RT. 27 RW. 02 are Muslim, so religious activities are often seen to be carried out in the community. Various kinds of religious activities of the community of Kelayan B RT. 27 RW. 02 such as congregational prayers in violation, the existence of arisan or yasinan groups for fathers and also mothers, majelis ta'lim, habsyi groups and the Al-Qur'an Education Park as well as activities to commemorate important Muslim days

According to Zakiah [2] religion provides answers to puzzling questions about the true meaning of life such as the purpose of life, why humans suffer, and the existence of life in the afterlife. Zakiah's opinion states that religion does not only affect aspects of the vertical relationship between humans and their gods or religious aspects of life, but also affects other aspects of life such as economic, social, and cultural. Religion can provide guidance about values such as good and bad or right and wrong of something. Religion directs us in directing us to issues of morality. People who are environmentally aware will not be careless because many people know the importance of the environment, but their behavior destroys the environment [3].

\section{METHOD}

This study uses an approach to qualitative. This research was conducted by collecting and studying various literature and literature studies. Data collection techniques use secondary data, which is obtained from various sources such as books, scientific journals, research body reports that are accurate and relevant to the concept religious activities of society. Data or information that has been obtained then made based on the results of the study of literature that is appropriate and can be justified. Analysis of the data in the article consists of two stages, namely the process of data reduction and data presentation. Data reduction is done to make it easier for writers to choose data from the literature validly while presenting data in narrative form. 


\section{RESULTS AND DISCUSSION 3.1 Religious Activities at Kelayan B RT. 27 RW.02}

Religious activities are all kinds of activities related to religion that become habits in everyday life so that they become guidelines in building relationships with Allah SWT, with fellow humans and the surrounding environment. Religious activities in Kelayan B Kelayan Timur Urban Village are carried out regularly every day, namely congregational prayers at the Tarbiatul Islamiyah and Al-Qur'an Education Park (TPQ / LPTQ) "MIN Kelayan". Activities that are carried out regularly every week such as arisan or yasinan for mothers are held on Thursday and yasinan for fathers is held on Thursday nights. In addition, there are also religious activities carried out by the community at certain times such as carrying out the Eid al-Fitr, namely zakat Fitrah and receiving zakat and Eid prayers.

\subsubsection{Religious Activities Conducted Every Day To Awaken To Protect The Environment}

\subsubsection{Congregational Prayers}

According to Rajab, language-based prayer is prayer, shalla-yushalla-salatan is the root word salat which means praying or establishing prayers. The word prayer is the plural of shalawat which means to confront the whole mind to prostrate, give thanks, and ask for help[4]. While prayer is based on terms from Hasbiyallah's opinion [5] is a form of worship which consists of certain actions and utterances starting with takbir and ending with greeting.

According to Ash-Shilawy [6]congregational prayer is a prayer done together, at least two people, one as the priest and one as the congregation. The congregational prayers that are carried out at the Tarbiatul Islamiyah violations are at dawn prayers, Asr prayers with children studying at TPQ / LTPQ MIN Kelayan, evening prayers and evening prayers. As a routine imam, Mr. H. Marwan, if he is unable to become an imam, the successor is Mr. Ahmad.

\subsubsection{TPQ/LTPQ "MIN Kelayan"}

The activities carried out at MIN Kelayan are reading iqro 'and Al-Quran, memorizing daily prayers and short surahs, practicing ablution and praying. There are two clerics who teach at MIN Kelayan, namely Mr. Ahmad and Mr. Nafis. Before starting learning, the children together read prayers before studying, read daily prayers and short surahs such as Al-Fatihah, Al-Ikhlas, Al-Falaq and An-Nas. After finishing reading the prayers one by one the children began to read the iqro or the Koran with Mr. Ahmad and Mr. Nafis. Until the time of the Asr prayer, the children were invited to perform ablution and guided to say the call to prayer and iqomah, and to carry out the Asr prayers in congregation who became the imam, Mr. Ahmad.

According to Muliawan [7]Taman Pendidikan Al-Qur'an (TPQ) is an Islamic educational institution at the primary level outside of schools. Al-Qur'an Education Park is an educational institution outside the school that serves as teaching the basics of worship in Islam. As stated by
Muhammad Nafis ( 30 years old), he explained that through various activities carried out at MIN Kelayan there is a learning process about prayer procedures and prayer practices so that children are provided with provisions from childhood on the importance of carrying out an obligation as a Muslim, namely carrying out prayers according to with Islamic law. As well as learning tajwid and religious knowledge, children can understand the importance of reading the Qur'an in accordance with the knowledge of recitation and the law. Character education is developing the basic abilities of students to think smart,[8]. In addition, habituation to clean living must be given from an early age both in formal schools, at home and at the TPQ because by teaching clean living, life becomes healthy. This habit can also train children to be responsible for themselves. Make those who join TPQ more sensitive or care about the environment they are in. It is important to protect the environment to increase people's environmental awareness, namely the existence of knowledge, concrete attitudes, and consistent behavior [9].

\subsubsection{Religious Activities Conducted Every Week}

\subsubsection{Arisan or yasinan mothers}

The social gathering activity for mothers is held every Thursday at Tarbiatul Islmiyah. The person in charge or chairman of the arisan or yasinan group is Mrs. Isnawati as well as the treasurer. The number of members of the arisan group is 40 people, each person is charged a fee of Rp. 5.000 ,- every week. The proceeds from the money collected are used to give lecturers, buy consumption, and the remainder of the money is stored as cash for common needs. The procedure for implementing arisan or yasinan for mothers, namely reading the first surah Al-Fatihah, AlIkhlas, Al-Falaq and An-Nas (chapter four) followed by reading surah yasin and ending with reading a prayer of congratulations. After that, it was continued by reading the dalail and prayers and the last was a religious lecture by teacher H. Marwan which discussed fiqh and tasauf.

Arisan groups or women's yasinan have been carried out continuously by the community for a long time, in accordance with the statement of Mrs. Isnawati (51 years) explaining that the activities of arisan or yasinan mothers have been going on for more than 30 years. Religious activities cannot be separated from people's lives, because this activity aims to establish ties between citizens, preserve a religion-based culture by reading the dalail and increase knowledge about religion by learning tasauf and fiqih as a basis for living life in the world and provision. for the end later.

Religious activity is also inseparable from the interaction between communities, both individually and with groups. From the existence of religious activities carried out by the community, it can lead to a self-approach to God Almighty and can increase understanding of religion so as to form an awareness of mutual respect and respect between communities so as to create harmonious and peaceful social relationships and make each other aware of environmental cleanliness wherever they are, especially in Kelayan. 
According to Muhsin[10]formulate that the functions and objectives of religious activities are: First as an educational and skills institution, second as a forum for activity and creativity, the third as a center for guidance and development, and fourth as a communication network, ukhuwah, and friendship. The fifth function and aims as a place for teaching and learning.

\subsubsection{Yasinan Ladies and Gentlemen}

The yasinan group, gentlemen, is a routine activity held every Thursday night after the evening prayer at the Tarbiatul Islamiyah dance. The yasinan group consists of 60 members as the chairman of Mr. M. Yusuf and the secretary of Mr. Usman. Each member is charged a fee of Rp. 5,000, - every week. The money from the fees is used to buy consumption needs such as mineral water and to give lecturers. The procedure for implementing yasinan gentlemen is not much different from arisan or yasinan for ladies, the only difference is that it is not accompanied by reading the dalail. First reading surah Al-Fatihah, Al-Ikhlas, Al-Falaq and Annas (surah four) followed by reading surah Yasin, Waqiah and Al-Mulk. Then proceed with a religious lecture by teacher $\mathrm{H}$. Marwan who discussed tasauf.

Following a yasinan can strengthen the relationship between people. Reading yasin and tahlil together can provide positive values for the readers. The existence of religious activities that are routinely carried out by fathers on Thursday nights as a form of the norms that apply in society that function as guidelines for social life and guidelines for belief in God Almighty.

\subsubsection{Diversity and Community Behavior Patterns towards protecting the Environment}

When discussing environmental issues, the point is to discuss how we as humans always interact and have an attitude of protecting nature, animals, plants and the environment in which we are. The lowest possible environment that we must pay attention to is the cleanliness of ourselves and the surrounding environment which has become a shared responsibility. However, so far, only a few people have awareness and care about the general environment such as not littering, then only a few people have a sense of environmental care so that a sense of belonging to the environment together does not exist. The life environment includes a very broad range, which has long-term benefits and impacts on the sustainability of human life on earth. Because basically the cause of environmental awareness in society is environmental ethics. The current environmental ethics is environmental ethics based on a value system that occupies humans not part of nature, but humans as conquerors and regulators of nature [11].

\subsubsection{Birthday of Prophet Muhammad SAW}

The birthday of the Prophet Muhammad SAW is held every year in violation of Tarbiatul Islamiyah and there are those who carry it out at home. The implementation of the birthday of the Prophet Muhammad SAW received $2 \mathrm{~kg}$ of meat donations from the aqiqah arisan group. The preparatory stage to commemorate the Prophet's Birthday from helping each other from cooking rice, cooking meat from donations to wrapping all the food. This activity is to commemorate the birthday of the Prophet Muhammad SAW, usually accompanied by reciting verses and prayers for the Prophet, joint dhikr and prayers. The activity of commemorating the birthday of the Prophet Muhammad SAW is a form of love and respect for the Prophet Muhammad SAW so that the implementation of this Mawlid can also be carried out continuously so that it is not lost by the changing times.

From this, a close relationship can be made in social life, as social beings who always need rocks from other people are generally found in every individual. There are many ways that can be done to show love to the Prophet, including imitating his morals, following his teachings, carrying out the sunnahs and praying to him. Of course, from all these services there is a blessing that is received if the intention to carry it out is only hoping for the pleasure of Allah SWT.

\section{CONCLUSION}

From the results of the above research it can be concluded that in fact religion (Islam) and the environment are inseparable. Because in the concept of Islam, the environment is introduced by the Koran in various ways. The religious activities of the Kelayan B community can never be separated from community life. As for some religious activities of the community of Kelayan B RT. 27 RW. 02. In fact, religious activities and the environment are inseparable. Because in the concept of religion, the environment is introduced by the Qur'an in various ways. Among them are al-bi'ah (occupying an area, living space and environment), namely the environment as a living space, especially for humans. Meanwhile, when one of the factors of religious activities in the community does not contribute to protecting the environment, it is due to the absence of religious materials delivered by religious leaders regarding the importance of protecting the surrounding environment. This is also due to the fact that religious social activities carried out by the community never contain study material about the environment. This results in later understanding that has developed in the community so far, religion and the environment are seen as two inseparable things and do not contribute adequately to each other. This is also due to the fact that religious social activities carried out by the community never contain study material about the environment. This results in later understanding that has developed in the community so far, religion and the environment are seen as two separate things and do not provide adequate contributions to each other. This is also due to the fact that religious social activities carried out by the community never contain study material about the environment. This results in later understanding that has developed in the community so far, religion and the environment are seen as two inseparable things and do not provide adequate contributions to each other.

Some religious activities carried out in Kelayan have gone well regarding socializing to the public that the environment 
is also an important matter to be discussed and carried out in every religious activity. Then, environmental awareness programs have been promoted, such as working together to clean the environment in Kelayan. Increase public knowledge about the environment.

\section{REFERENCES}

[1] B. Sulistyowati and S. Soekanto, Sosiologi Suatu Pengantar. Jakarta: Raja Grafindo Persada, 2014.

[2] Z. Daradjat, Ilmu Pendidikan Islam. Jakarta: Bumi Aksara, 2008.

[3] M. R. N. Handy, Mutiani, M. A. H. Putra, and Jumriani, "The Religious Values in Tradition of Batahlil in Banjar Pahuluan Community," Kalimantan Soc. Stud. J., vol. 2, no. 1, pp. 39-47, 2020.

[4] K. Rajab, "Psikologi Ibadah Memakmurkan Kerajaan Ilahi di Hati Manusia," Pekanbaru: Amzah, 2011.
[5] Hasbiyallah, Fiqh dan Ushul Fiqh Metode Istinbath dan Istidlal. Bandung: Remaja Rosdakarya, 2013.

[6] I. R. Ash-Shilawy, Panduan Lengkap Ibadah Shalat. Yogyakarta: Citra Risalah, 2009.

[7] J. U. Muliawan, Pendidikan Islam Integratif. Yogyakarta: Pustaka Belajar, 2015.

[8] M. A. H. Putra, "Building Character Education Through The Civilization Nations Children," Kalimantan Soc. Stud. J., vol. 1, no. 1, pp. 12-17, 2019.

[9] M. A. H. Putra, Mutiani, Jumriani, and M. R. N. Handy, "The Development of a Waste Bank as a Form of Community Participation in Waste Management," Kalimantan Soc. Stud. J., vol. 1, no. 1, pp. 22-30, 2020.

[10] M. Harianto, Fiqih Kontemporer. Yogyakarta: Kapita Salekta, 2009.

[11] A. Neolaka, Kesadaran Lingkungan. Jakarta: Rineka Cipta, 2017. 